\title{
MILD DROUGHT IN INTERACTION WITH ADDITIONAL NITROGEN DOSE AT GRAIN FILLING STAGE MODULATES 2- ACETYL-1-PYRROLINE BIOSYNTHESIS AND GRAIN YIELD IN FRAGRANT RICE
}

\author{
DENG, Q. Q. ${ }^{1,2}-$ ASHRAF, U. ${ }^{1,2,3}$ - CHENG, S. R. ${ }^{1,2}-$ SABIR, S. R. ${ }^{4}-$ Mo, Z. W. ${ }^{1,2}-$ PAN, S. G. ${ }^{1,2}-$ \\ TIAN, H. ${ }^{1,2}$ - DUAN, M. Y. ${ }^{1,2}-$ TANG, X. R. ${ }^{1,2 *}$ \\ ${ }^{I}$ Department of Crop Science and Technology, College of Agriculture, South China Agricultural \\ University, Guangzhou, Guangdong 510642, China
}

${ }^{2}$ Scientific Observing and Experimental Station of Crop Cultivation in South China, Ministry of Agriculture, P. R. China, Guangzhou, Guangdong 510642, China
${ }^{3}$ Department of Botany, University of Education (Lahore), Faisalabad-Campus, Faisalabad, 38000 Punjab, Pakistan

${ }^{4}$ State Key Laboratory of Grassland Agroecosystem, School of Life Sciences, Lanzhou University, Lanzhou, China

*Corresponding author

e-mail:tangxr@scau.edu.cn; phone/fax:020-85280204-618

(Received 29 $9^{\text {th }}$ Jul 2018; accepted $11^{\text {th }}$ Oct 2018)

\begin{abstract}
Field experiments were conducted to investigate the influence of varying levels of water and nitrogen at grain filling stage on 2-acetyl-1-pyrroline (2-AP) content, enzymes activities and grain yield of fragrant rice (Oryza sativa L.). Two fragrant rice cultivars i.e., 'Basmati 385' and 'Nongxiang 18', were grown under two water treatments i.e., W1: well-watered (water layer 4-6 cm) and W2: mild soil drought, (the soil water potential was $-(25 \pm 5 \mathrm{kPa}))$ from full heading stage to maturity during early and late season, 2014 at South China Agricultural University, Guangzhou, China. Two nitrogen levels i.e., N1: $15 \mathrm{~kg} \mathrm{hm}^{-2}$ and N2: $30 \mathrm{~kg} \mathrm{hm}^{-2}$ were applied at heading stage. Results showed that the W2 and N1 treatment improved 2-AP content in brown rice for both cultivars. Higher 2-AP content was observed in the W2N1 treatment in 'Basmati 385' (26.22 and 136.29 $\left.\mathrm{ng} \mathrm{g}^{-1}\right)$ and 'Nongxiang 18' (23.47 and $66.48 \mathrm{ng}$ $\mathrm{g}^{-1}$ ). Moreover, 2-AP content in brown rice showed positive correlation with proline dehydrogenase (PDH) activity whilst showed negative correlation with proline content in grains during both seasons. In addition, 2-AP content in brown rice showed significantly negative correlation with proline for early season, but significant and positive correlation with PDH activity in grains for late season. During early season, all treatments were found no statistically difference for grain yield of both rice cultivars, whereas the highest grain yield i.e., 7.39 and $8.07 \mathrm{t} \mathrm{hm}^{-2}$ was obtained under W2N1 treatment in 'Basmati 385' and 'Nongxiang 18', respectively during late season. In conclusion, mild drought conditions in combination with the $\mathrm{N}$ application at $15 \mathrm{~kg} \mathrm{hm}^{-2}$ at grain filling stage could promote grain yield and 2AP content in brown rice.
\end{abstract}

Keywords: aromatic rice, enzymes, fragrance, nitrogen, water stress, yield

\section{Introduction}

Fragrant rice (Oryza sativa L.) is the most popular rice type due to its pleasant and exquisite aroma (Bryant and McClung, 2011; Ashraf et al., 2017a, b). 'Basmati' from India and Pakistan, and 'Jasmine' rice from Thailand are two major types of fragrant rice that are consumed widely (Bhattacharjee et al., 2002; Ashraf et al., 2017c). Due to its unique flavor and superior grain qualities, the fragrant rice fetches premium prices in 
international markets and demands are grown dramatically in recent years (Sakthivel et al., 2009). The distinct 'popcorn' or 'pandan' like flavor of fragrant rice is quite complicated, however the most important one is identified as 2-acetyl-1-pyrroline (2AP) (Buttery et al., 1982; Buttery et al., 1983). Proline is considered to be an important precursor of 2-AP formation in aromatic rice (Yoshihashi et al., 2002).

Previously, the betaine aldehyde dehydrogenase gene (OsBADH2) on chromosome 8 was identified to have a great affinity towards the formation of 2-AP in aromatic rice (Bradbury et al., 2005a; Kovach et al., 2009). $\gamma$-amino-butyraldehyde (AB-ald) is an immediate precursor of 2-AP synthesis, which can be oxidized into 4-aminobutyric acid (GABA) under the catalysis of the full-length OsBADH2 protein encoded by OsBADH2 gene (Wongpanya et al., 2011). In fragrant rice, three single nucleotide polymorphisms (SNPs) and an 8 bp deletion in the seventh exon of OsBADH2 gene produced a premature stop codon that putatively disables the OsBADH2 protein (Bradbury et al., 2005b, 2008; Shi et al., 2008). Thus the mutation resulted in the accumulation of AB-ald and the subsequent formation of 2-AP (Kovach et al., 2009), in utmost famous aromatic rice varieties i.e., Jasmine and Basmati (Myint et al., 2012). However, some studies have showed that there are exceptions to this mutation, other genetic loci or null OsBADH2 allele are also implicated in the controlling of the aroma trait, which proposed the genetic differences for 2-AP formation among fragrant rice cultivars (Shi et al., 2008; Sakthivel et al., 2009).

In addition to genetic factors, the 2-AP in fragrant rice is also affected by environmental and crop management factors as well as cultivation practices (Gay et al., 2010). Besides affecting growth and yield, water and nitrogen fertilizer affect the physiology of aroma formation in fragrant rice (Haefele et al., 2008). The soil nitrogen content is directly or indirectly related to the proline content and aroma synthesis in aromatic rice (Yang et al., 2012). Alternate wetting and drying (AWD) irrigation is one of the most widely used water-saving method in rice (Cabangon et al., 2011; Ye et al., 2013). Recent studies have suggested that AWD in combination with fertilization management such as adding appropriate amount of nitrogenous fertilizers (Pan et al., 2009), site-specific nitrogen management (SSNM) (Liu et al., 2013; Xue et al., 2013), and applying controlled-release nitrogen fertilizer (Ye et al., 2013) not only enhances grain yield but also improves resource-use efficiency. Furthermore, water-nitrogen dynamics and moderate soil drying/mild drought conditions (the minimum soil water potential: $-25 \mathrm{kPa}$ ) had substantial effects on 2 -AP content in aromatic rice (Ren et al., 2017).

Grain filling stage is crucial for yield and quality traits in fragrant rice. Therefore, it is of great interest to study some management factors such as water and nitrogen during this period for quality rice production with higher yields. Water regulations or milddrought like conditions can be practiced from tillering to maturity stages; however, some researchers suggested that water or nitrogen management during grain filling period should be focused for better assessment of quality regulations in fragrant rice (Cai et al., 2006, 2015; Li et al., 2008; Liu et al., 2012). Although plenty of literature is available on nitrogen and water based studies on growth and yield of rice; however effects of nitrogen and water regulations during grain filling period on rice aroma formation and the activities of enzymes involved in 2-AP biosynthesis are rarely investigated. Therefore, this study was executed to evaluate the effects of water and nitrogen regulations at grain filling stage on 2 -AP and $\Delta^{1}$-pyrroline-5-carboxylic acid (P5C) accumulation and enzymes involved in 2-AP biosynthesis i.e., proline 
dehydrogenase (PDH), ornithine aminotransferase (OAT), $\Delta^{1}$-pyrroline-5-carboxylic acid synthetase (P5CS) in fragrant rice.

\section{Materials and methods}

\section{Experimental site description}

Two aromatic rice cultivars i.e., 'Basmati 385' and 'Nongxiang 18' were gown in early (March-July) and late (July-November) seasons 2014 at Experimental Research Farm, South China Agricultural University, Guangzhou, China $\left(23^{\circ} 09^{\prime} \mathrm{N}, 113^{\circ} 21^{\prime} \mathrm{E}\right.$ and $11 \mathrm{~m}$ above the sea level). This region is characterized by a humid subtropical monsoonal climate with $2234.0 \mathrm{~mm}$ mean annual rainfall and $21.7^{\circ} \mathrm{C}$ mean annual air temperature (Fig. 1). The properties of experimental soil were listed in Table 1.

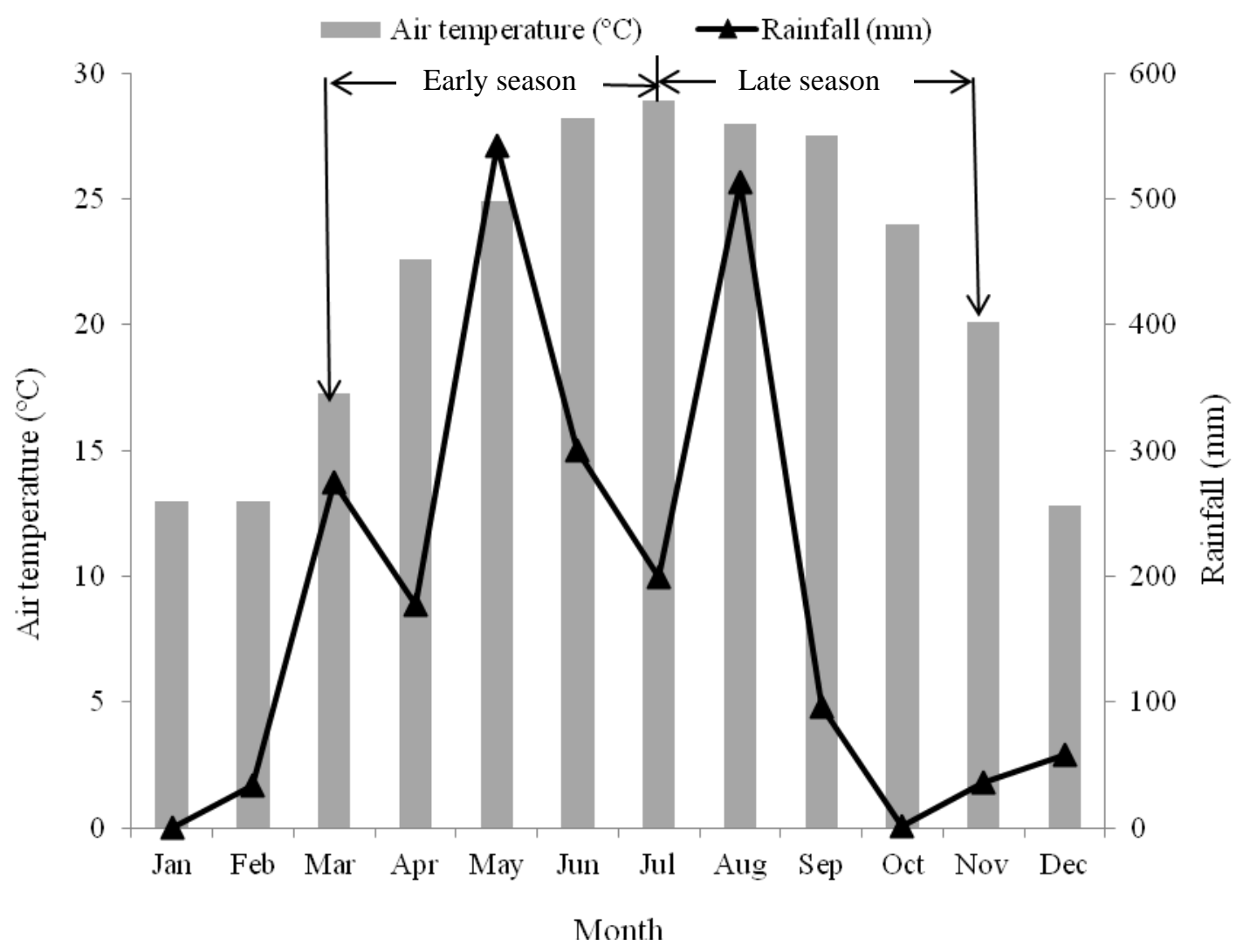

Figure 1. Monthly mean temperature and monthly cumulative rainfall of the experimental site during early and late rice season 2014

Table 1. The physico-chemical properties of experimental soil during both early and late seasons

\begin{tabular}{c|c|c|c|c|c}
\hline Seasons & Soil texture & $\begin{array}{c}\text { Organic matter } \\
\left(\mathbf{g ~ k g}^{-\mathbf{1}}\right)\end{array}$ & $\begin{array}{c}\text { Total N } \\
\left(\mathbf{g ~ k g}^{-\mathbf{1}}\right)\end{array}$ & $\begin{array}{c}\text { Total P } \\
\left(\mathbf{g ~ k g}^{-1}\right)\end{array}$ & $\begin{array}{c}\text { Total K } \\
\left(\mathbf{g ~ k g}^{-1}\right)\end{array}$ \\
\hline Early season & Sandy loam & 21.71 & 1.20 & 1.10 & 24.30 \\
\hline Late season & Sandy loam & 21.74 & 1.70 & 1.30 & 20.10 \\
\hline
\end{tabular}




\section{Experimental design}

The experiments were arranged in a split-plot design in triplicate. The water regimes i.e., (1) W1: well-watered, 4-6 cm; (2) W2: moderate drought, the minimum water potential was $-(25 \pm 5) \mathrm{kPa}$ at grain filling stage were randomized it main plots, whilst the nitrogen levels i.e., $\mathrm{N} 1: 15 \mathrm{~kg}$ and $\mathrm{N} 2: 30 \mathrm{~kg} \mathrm{~N} \mathrm{hm}^{-2}$ were assigned to sub-plots. These nitrogen doses were applied at the heading stage. In addition to nitrogen treatments, $90 \mathrm{~kg} \mathrm{hm}^{-2} \mathrm{~N}, 90 \mathrm{~kg} \mathrm{hm}^{-2} \mathrm{P}_{2} \mathrm{O}_{5}$ and $195 \mathrm{~kg} \mathrm{hm}^{-2} \mathrm{~K}_{2} \mathrm{O}$ were applied at basal dose in all the treatments, whereas $\mathrm{N}$ at $30 \mathrm{~kg} \mathrm{hm}^{-2}$ was applied at tillering stage as per recommendation of the province. Fertilizers were applied in the form of urea, calcium superphosphate, and potassium chloride. The area for each subplot was about $13 \mathrm{~m}^{2}$. The seeds of both cultivars were sown on March 11th and July 18th in early and late seasons, respectively. Seedlings were transplanted on April 5th and August 3th at $20 \mathrm{~cm}$ $\times 20 \mathrm{~cm}$ spacing with two seedlings per hill. During the whole growth period, other field management practices were kept similar for all the treatments by following the provincial guidelines. Harvesting was done on July 11 and November 4, 2014 for early and late seasons, respectively.

\section{Measurements}

At maturity, $1 \mathrm{~m}^{2}$ from each experimental plot was reaped, threshed and sun dried (adjusted to $\sim 14 \%$ moisture content) to determine the grain yield. Rice paddy was threshed by using THU356 type threshing machine (Satake Machinery Co., Ltd.) to get brown rice (as a test sample of 2-AP). Ten randomly selected hills from each plot were chosen to record the number of panicles in triplicate. Plants from four randomly selected hills from each plot were sampled to determine grains per panicle, filled grain percentage, and 1000-grain weight.

The fresh grains $(15 \mathrm{~g})$ and flag leaves $(10 \mathrm{~g})$ from each treatment were sampled at physiological maturity and immediately stored at $-80{ }^{\circ} \mathrm{C}$ till biochemical analyses. The 2-AP content in brown rice was determined following the method devised by Huang et al. (2012) by combining the synchronization distillation and extraction method (SDE) with GCMS-QP 2010 Plus (Shimadzu Corporation, Japan) expressed as $\mathrm{ng} \mathrm{g}^{-1}$.

The proline content in leaves and grains were determined according to Bates et al. (1973). Fresh leaves ( $0.3 \mathrm{~g})$ or grains $(0.3 \mathrm{~g})$, the grains were stripped of the glumes by hand, were homogenized in $4 \mathrm{~mL}$ of $3 \%$ sulfosalicylic acid, and cooled down after heated in boiling water for $10 \mathrm{~min}$. Samples were filtered and $2 \mathrm{ml}$ of the filtrate was mixed with $2 \mathrm{~mL}$ ninhydrin reagent $(5 \mathrm{~g}$ ninhydrin in $120 \mathrm{~mL}$ glacial acetic acid and $80 \mathrm{~mL} 6 \mathrm{M}$ phosphoric acid) and $2 \mathrm{~mL}$ glacial acetic acid. The reaction mixture was heated at $100^{\circ} \mathrm{C}$ for $30 \mathrm{~min}$ in a water bath and added $4 \mathrm{ml}$ of toluene after it was cooled. The toluene mixture was centrifuged at $4000 \mathrm{rpm}$ for $5 \mathrm{~min}$ and proline absorbance was measured at $520 \mathrm{~nm}$. The proline contents were estimated by a standard curve.

The P5C contents in leaves and grains were measured as described by $\mathrm{Wu}$ et al. (2009). The reaction mixture contained $0.375 \mathrm{ml}$ supernatant of enzyme solution, $0.5 \mathrm{ml}$ of $10 \%$ trichloroacetic acid (TCA) and $0.125 \mathrm{ml}$ of $0.25 \%$ 2-aminobenzaldehyde. The sample was kept for $30 \mathrm{~min}$ at room temperature, and then centrifuged at $14000 \times \mathrm{g}$ for $10 \mathrm{~min}$. After centrifugation, the absorbance was assayed at $440 \mathrm{~nm}$. An extinction coefficient $\left(2.58 \mathrm{mM}^{-1} \mathrm{~cm}^{-1}\right)$ was used for determining the concentration of P5C. 
Fresh leaves $(0.3 \mathrm{~g})$ or grains samples $(0.3 \mathrm{~g})$, the grains were stripped of the glumes by hand, were homogenized in $8 \mathrm{ml}$ of $50 \mathrm{mM}$ Tris-HCl buffer ( $\mathrm{pH} 7.5$ ) containing 1.0 $\mathrm{mM} \mathrm{KCl}, 7.0 \mathrm{mM} \mathrm{MgCl} 2,1 \%$ glycerin, $5 \%$ insoluble polyvinyl polypyrrolidone (PVP), $3.0 \mathrm{mM}$ ethylenediamine tetra-acetic acid (EDTA) and $1.0 \mathrm{mM}$ dithiothreitol (DTT). The homogenate was centrifuged at $8000 \mathrm{rpm}$ for $20 \mathrm{~min}$ at $4{ }^{\circ} \mathrm{C}$ and the supernatants were used for determining the proline dehydrogenase (PDH), ornithine aminotransferase (OAT) and $\triangle^{1}$ pyrroline 5-carboxylic acid synthase (P5CS) activities.

Proline dehydrogenase (PDH) activity was determined according to Ncube et al. (2013). The reaction mixture contained $100 \mathrm{mM}$ phosphate buffer ( $\mathrm{pH} 7.4), 0.01 \mathrm{mM}$ cytochrome c, $0.5 \%(\mathrm{v} / \mathrm{v})$ Triton X-100, $15 \mathrm{mM}$ L-proline and $0.2 \mathrm{ml}$ enzyme extract in a total volume of $1 \mathrm{ml}$ was reacted at $37^{\circ} \mathrm{C}$ for $30 \mathrm{~min}$ and $1 \mathrm{ml} 10 \%$ TCA was used to stop the reaction and then $1 \mathrm{ml} 0.5 \%$ 2-aminobenzaldehyde in $95 \%$ ethanol to measure the P5C contents. The mixture was further reacted for $10 \mathrm{~min}$ at $37^{\circ} \mathrm{C}$ and centrifuged for $10 \mathrm{~min}$ at $8000 \mathrm{rpm}$ and the supernatant was used to measure the absorbance at 440 $\mathrm{nm}$. The molar extinction coefficient of $\left(2.71 \times 10^{3} \mathrm{~min}^{-1} \mathrm{~cm}^{-1}\right)$ was used to estimate PDH activity.

Activity of $\Delta^{1}$-pyrroline-5-carboxylic acid synthetase (P5CS) was assayed according to Zhang et al. (1995). Reaction mixture $(0.5 \mathrm{ml})$ was comprised of $50 \mathrm{mM}$ Trise $\mathrm{HCl}$ buffer (pH 7.0), $10 \mathrm{mM}$ ATP, $100 \mathrm{mM}$ hydroxamate-HCl, $50 \mathrm{mM}$ L-glutamate, 20.0 $\mathrm{mM} \mathrm{MgCl}$, and $0.5 \mathrm{ml}$ of enzyme extract. The reaction was carried out for $5 \mathrm{~min}$ in water bath at $37{ }^{\circ} \mathrm{C}$. The reaction was stopped by adding $0.5 \mathrm{ml}$ of a stop buffer i.e., $2.5 \%$ of $\mathrm{FeCl}_{3}$ plus $6 \%$ of TCA, dissolved in $100 \mathrm{ml}$ of $2.5 \mathrm{~mol} / \mathrm{L} \mathrm{HCl}$.

Ornithine aminotransferase (OAT) activity was determined according to Chen et al. (2001). The reaction mixture contained $100 \mathrm{mM}$ potassium phosphate buffer ( $\mathrm{pH}$ 8.0), 1 $\mathrm{mM}$ pyridoxal-5-phosphate, $50 \mathrm{mM}$ ornithine, $20 \mathrm{mM} \alpha$-ketoglutarate, and the enzyme extract $(0.1 \mathrm{ml})$. After incubation of the assay mixture for $30 \mathrm{~min}$ at $37^{\circ} \mathrm{C}$, the reaction was stopped by adding $0.5 \mathrm{ml} 10 \%$ trichloroacetic acid (TCA) then added $0.5 \mathrm{ml}$ of $0.25 \%$ 2-aminobenzaldehyde (dissolved in 95\% ethanol) for color reaction for $60 \mathrm{~min}$. After centrifugation at $8000 \mathrm{rpm}$ for $10 \mathrm{~min}$, absorbance of the clear supernatant fraction was measured at $440 \mathrm{~nm}$. An extinction coefficient $\left(2.68 \mathrm{mM}^{-1} \mathrm{~cm}^{-1}\right)$ was used for calculating the OAT activity

\section{Statistical analysis}

The data were analyzed by two-factor analysis of variance technique to assess significance of the respective treatments for 2-AP, proline and enzymes involved in 2AP biosynthesis, yield, and related traits with computer software Statistix 8 (Analytical software, Tallahassee, Florida, USA), whereas differences amongst treatments were separated by least significant difference (LSD) test at 5\% probability level.

\section{Results}

\section{The 2-AP content in brown rice}

The effects of water $(\mathrm{W})$, nitrogen $(\mathrm{N})$ and their interaction $(\mathrm{W} \times \mathrm{N})$ were remained statistically similar $(\mathrm{P}>0.05)$ for 2 -AP content in brown rice during early season. During late season, W2 treatment significantly increased the 2-AP content in brown rice in 'Basmati 385 ' by $43.22 \%$, whilst no significant difference was observed for 'Nongxiang 18' for both water treatments. Besides, N1 treatment substantially 
improved 2-AP content in 'Basmati 385 ' and 'Nongxiang 18 ' by $31.70 \%$ and $7.00 \%$, respectively. In addition, the highest 2 -AP content was observed under W2N1 i.e., $136.29 \mathrm{ng} \mathrm{g}^{-1}$ and $66.48 \mathrm{ng} \mathrm{g}^{-1}$ for 'Basmati 385 ' and 'Nongxiang 18', respectively. The aroma content of brown rice in the late season of two fragrant rice cultivars was higher than that in early season, and the 2-AP content in 'Basmati 385' was higher than that in 'Nongxiang 18'. The 2-AP content in the treatment in 'Basmati 385' of W2N1 was significantly higher than that of other interaction treatments, 'Nongxiang 18' had a higher 2-AP content in W2N1 treatment, which was significantly higher than W1N1 and W2N2. Hence, mild drought and appropriate nitrogen application could increase the 2-AP content in brown rice (Table 2).

Table 2. Effect of mild drought and nitrogen on the 2-AP content in brown rice

\begin{tabular}{|c|c|c|c|c|}
\hline \multirow[b]{2}{*}{ Treatments } & \multicolumn{2}{|c|}{ Early season } & \multicolumn{2}{|c|}{ Late season } \\
\hline & $\begin{array}{c}\text { Basmati } 385 \\
\left(\text { ng g }^{-1}\right)\end{array}$ & $\begin{array}{c}\text { Nongxiang18 } \\
\left(\mathrm{ng} \mathrm{g}^{-1}\right)\end{array}$ & $\begin{array}{c}\text { Basmati } 385 \\
\left(\text { ng g }^{-1}\right)\end{array}$ & $\begin{array}{c}\text { Nongxiang18 } \\
\left(\mathrm{ng} \mathrm{g}^{-1}\right)\end{array}$ \\
\hline W1 & $28.38 \mathrm{a}$ & $19.08 \mathrm{a}$ & $86.51 \mathrm{~b}$ & $55.60 \mathrm{a}$ \\
\hline W2 & $27.64 \mathrm{a}$ & $22.06 \mathrm{a}$ & $123.90 \mathrm{a}$ & $57.64 \mathrm{a}$ \\
\hline $\mathrm{N} 1$ & $25.90 \mathrm{a}$ & $20.71 \mathrm{a}$ & $119.58 \mathrm{a}$ & $58.54 \mathrm{a}$ \\
\hline $\mathrm{N} 2$ & $30.12 \mathrm{a}$ & $20.43 a$ & $90.83 b$ & $54.70 \mathrm{~b}$ \\
\hline W1N1 & $25.59 \mathrm{a}$ & $17.95 \mathrm{a}$ & $102.86 \mathrm{c}$ & $50.59 \mathrm{~b}$ \\
\hline $\mathrm{W} 1 \mathrm{~N} 2$ & $31.17 \mathrm{a}$ & $20.21 \mathrm{a}$ & $70.16 \mathrm{~d}$ & $60.61 \mathrm{a}$ \\
\hline W2N1 & $26.22 \mathrm{a}$ & $23.47 \mathrm{a}$ & $136.29 \mathrm{a}$ & $66.48 \mathrm{a}$ \\
\hline W2N2 & $29.06 \mathrm{a}$ & $20.64 a$ & $111.50 \mathrm{~b}$ & $48.79 b$ \\
\hline
\end{tabular}

Means with different lower-case letter in the same column for the same variety under the same treatments show significant difference at $\mathrm{P}=0.05$ by LSD tests. $\mathrm{W} 1$ : well-watered $(4-6 \mathrm{~cm}$ water layer), W2: moderate drought, soil water potential $(-25 \pm 5 \mathrm{kPa}) ; \mathrm{N} 1: 15 \mathrm{~kg} \mathrm{~N} \mathrm{hm}^{-2}, \mathrm{~N} 2: 30 \mathrm{~kg} \mathrm{~N} \mathrm{hm}^{-2}$

\section{Proline content and activities of enzymes involved in 2-AP biosynthesis in grains}

Regarding water treatments, mild drought (W2) treatment significantly decreased P5CS activity during early season whilst increased OAT activity in 'Basmati 385' during late season. W2 treatment also led to substantial increase in proline content and PDH activity in grains of 'Nongxiang 18' during early season. For N treatments, N1 treatment significantly increased PDH activity in grains of 'Nongxiang 18' during late season, however decreased OAT activity significantly in grains of 'Basmati 385' during early season. During early season, maximum OAT activity was recorded under W1N2 for 'Basmati 385' whilst for 'Nongxiang 18', highest OAT activity was recorded under W2N1 which was also statistically similar $(\mathrm{p}>0.05)$ with W1N2 and W2N2. During late season, both rice cultivars were found no statistically difference for P5C content during early season as well as for late season (only for 'Nongxiang 18'). Furthermore, W2N1 and W2N2 treatments significantly increased PDH activity in grains of 'Nongxiang 18' during early season (Table 3).

The proline content, PDH and OAT (except W1N1) activities of 'Nongxiang 18' in early season were higher than that in late season. The PDH activity of 'Basmati $385^{\text {' }}$ in early season was higher than that in late season. The OAT (except W1N2), P5CS activities and P5C content (except W1N2) of 'Basmati 385' in late season were higher 
than that in early season. The P5C content of 'Nongxiang 18' in late season was higher than that in early season.

Table 3. Effect of mild drought and nitrogen on proline and enzymes involved in 2-AP biosynthesis in grains of fragrant rice

\begin{tabular}{|c|c|c|c|c|c|c|c|c|c|c|}
\hline \multirow[b]{2}{*}{ 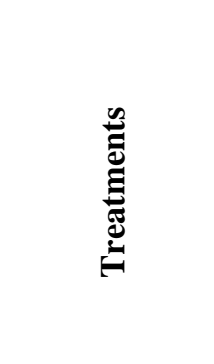 } & \multicolumn{5}{|c|}{ Early season } & \multicolumn{5}{|c|}{ Late season } \\
\hline & 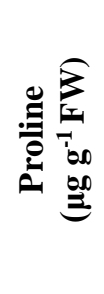 & 胥 & 竞 & 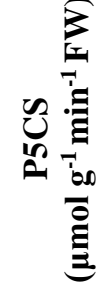 & مُ & 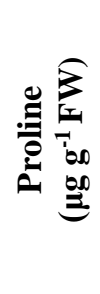 & 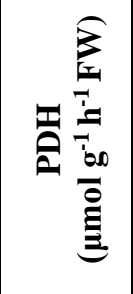 & 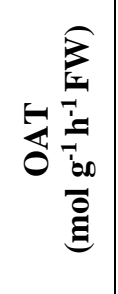 & 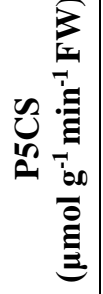 & مُ \\
\hline Basmati 38 & & & & & & & & & & \\
\hline W1 & $5.13 \mathrm{a}$ & $59.12 \mathrm{a}$ & 23.91a & $0.99 \mathrm{a}$ & $0.50 \mathrm{a}$ & $5.13 \mathrm{a}$ & $39.91 \mathrm{a}$ & $22.29 b$ & $1.17 \mathrm{a}$ & $0.45 \mathrm{a}$ \\
\hline W2 & $5.33 \mathrm{a}$ & $51.71 \mathrm{a}$ & $23.18 \mathrm{a}$ & $0.82 \mathrm{~b}$ & $0.44 \mathrm{a}$ & $5.32 \mathrm{a}$ & $43.08 \mathrm{a}$ & $25.57 \mathrm{a}$ & $1.26 \mathrm{a}$ & $0.47 \mathrm{a}$ \\
\hline $\mathrm{N} 1$ & $5.24 \mathrm{a}$ & $53.23 \mathrm{a}$ & $21.82 b$ & $0.84 \mathrm{a}$ & $0.43 \mathrm{a}$ & $5.20 \mathrm{a}$ & $41.39 \mathrm{a}$ & $24.57 \mathrm{a}$ & $0.97 \mathrm{a}$ & $0.51 \mathrm{a}$ \\
\hline $\mathrm{N} 2$ & $5.22 \mathrm{a}$ & $57.60 \mathrm{a}$ & $25.27 \mathrm{a}$ & $0.98 \mathrm{a}$ & $0.52 \mathrm{a}$ & $5.25 \mathrm{a}$ & $41.60 \mathrm{a}$ & $23.28 \mathrm{a}$ & $1.46 \mathrm{a}$ & $0.41 \mathrm{a}$ \\
\hline W1N1 & $5.10 \mathrm{a}$ & $51.99 \mathrm{a}$ & $22.05 b$ & $0.92 \mathrm{a}$ & $0.43 \mathrm{a}$ & $5.03 \mathrm{a}$ & $41.32 \mathrm{ab}$ & $23.60 \mathrm{a}$ & $0.98 \mathrm{a}$ & $0.54 \mathrm{a}$ \\
\hline W1N2 & $5.16 \mathrm{a}$ & $66.25 \mathrm{a}$ & $25.77 \mathrm{a}$ & $1.07 \mathrm{a}$ & $0.58 \mathrm{a}$ & $5.23 \mathrm{a}$ & $38.49 \mathrm{~b}$ & $20.98 b$ & $1.36 \mathrm{a}$ & $0.36 \mathrm{~b}$ \\
\hline W2N1 & $5.38 \mathrm{a}$ & $54.48 \mathrm{a}$ & $21.58 b$ & $0.76 \mathrm{a}$ & $0.44 \mathrm{a}$ & $5.37 \mathrm{a}$ & $41.46 \mathrm{ab}$ & $25.55 \mathrm{a}$ & $0.95 \mathrm{a}$ & $0.48 \mathrm{ab}$ \\
\hline W2N2 & $5.27 \mathrm{a}$ & $48.95 a$ & $24.77 \mathrm{ab}$ & $0.88 \mathrm{a}$ & $0.45 \mathrm{a}$ & $5.28 \mathrm{a}$ & $44.71 \mathrm{a}$ & $25.59 \mathrm{a}$ & $1.57 \mathrm{a}$ & $0.47 \mathrm{ab}$ \\
\hline Nongxiang & & & & & & & & & & \\
\hline W1 & $6.49 \mathrm{~b}$ & $41.69 \mathrm{~b}$ & $25.20 \mathrm{a}$ & $1.06 \mathrm{a}$ & $0.48 \mathrm{a}$ & $5.40 \mathrm{a}$ & $38.39 \mathrm{a}$ & $25.27 \mathrm{a}$ & $1.04 \mathrm{a}$ & $0.56 a$ \\
\hline W2 & $7.47 \mathrm{a}$ & $61.33 \mathrm{a}$ & $28.05 \mathrm{a}$ & $0.97 \mathrm{a}$ & $0.51 \mathrm{a}$ & $5.97 \mathrm{a}$ & $38.43 \mathrm{a}$ & $25.25 \mathrm{a}$ & $0.94 \mathrm{a}$ & $0.58 \mathrm{a}$ \\
\hline $\mathrm{N} 1$ & $6.91 \mathrm{a}$ & $51.93 \mathrm{a}$ & $26.39 \mathrm{a}$ & $0.99 \mathrm{a}$ & $0.49 \mathrm{a}$ & $5.89 \mathrm{a}$ & $39.08 \mathrm{a}$ & $25.45 \mathrm{a}$ & $1.01 \mathrm{a}$ & $0.60 \mathrm{a}$ \\
\hline $\mathrm{N} 2$ & $7.05 a$ & $51.09 \mathrm{a}$ & $26.86 a$ & $1.04 \mathrm{a}$ & $0.50 \mathrm{a}$ & $5.48 \mathrm{a}$ & $37.74 b$ & $25.07 \mathrm{a}$ & $0.97 \mathrm{a}$ & $0.54 a$ \\
\hline W1N1 & $6.40 \mathrm{a}$ & $43.77 \mathrm{~b}$ & $24.11 \mathrm{~b}$ & $0.99 \mathrm{a}$ & $0.47 \mathrm{a}$ & $5.61 \mathrm{a}$ & $38.99 \mathrm{a}$ & $25.50 \mathrm{a}$ & $1.12 \mathrm{a}$ & $0.59 a$ \\
\hline W1N2 & $6.58 \mathrm{a}$ & $39.62 b$ & 26.28ab & $1.14 \mathrm{a}$ & $0.49 \mathrm{a}$ & $5.19 \mathrm{a}$ & $37.79 \mathrm{a}$ & $25.05 \mathrm{a}$ & $0.96 \mathrm{a}$ & $0.53 a$ \\
\hline W2N1 & $7.42 \mathrm{a}$ & $60.10 \mathrm{a}$ & $28.67 \mathrm{a}$ & $0.99 \mathrm{a}$ & $0.51 \mathrm{a}$ & $6.16 \mathrm{a}$ & $39.16 \mathrm{a}$ & $25.40 \mathrm{a}$ & $0.90 \mathrm{a}$ & $0.60 \mathrm{a}$ \\
\hline W2N2 & $7.51 \mathrm{a}$ & $62.56 \mathrm{a}$ & 27.44ab & $0.94 \mathrm{a}$ & $0.51 \mathrm{a}$ & $5.78 \mathrm{a}$ & $37.70 \mathrm{a}$ & $25.10 \mathrm{a}$ & $0.98 \mathrm{a}$ & $0.56 \mathrm{a}$ \\
\hline
\end{tabular}

Means with different lower-case letter in the same column for the same variety under the same treatments show significant difference at $\mathrm{P}=0.05$ by LSD tests. W1: well-watered $(4-6 \mathrm{~cm}$ water layer, W2: moderate drought, soil water potential $(-25 \pm 5 \mathrm{kPa})$; N1: $15 \mathrm{~kg} \mathrm{~N} \mathrm{hm}^{-2}, \mathrm{~N} 2: 30 \mathrm{~kg} \mathrm{~N} \mathrm{hm}^{-2}$. PDH: Proline dehydrogenase; OAT: ornithine aminotransferase; P5CS: $\Delta^{1}$-pyrroline-5-carboxylic acid synthetase; P5C: $\Delta^{1}$-pyrroline-5-carboxylic acid

For 'Basmati 385', P5CS activity of 'Basmati 385' in late season (except W1N1) was higher than that in 'Nongxiang 18'. For 'Nongxiang 18', the proline content, OAT, P5CS activities and P5C content (except W1N2) of 'Nongxiang 18' in early season were higher than that in 'Basmati 385'. The proline and P5C contents of 'Nongxiang 18 ' in late season were higher than that in 'Basmati 385 '.

In early season, the OAT activity of W1N2 treatment in 'Basmati 385' was the highest, significantly higher than that of $\mathrm{W} 1 \mathrm{~N} 1$ and $\mathrm{W} 2 \mathrm{~N} 1, \mathrm{~W} 2 \mathrm{~N} 2$ was not significantly different from W1N2. In late season, the PDH and OAT activities of W2N2 treatment in 'Basmati 385' were the highest, significantly higher than that of W1N2, the rest was not significantly different from W2N2. In late season, the P5C content of 'Basmati 385' 
under W1N1 treatment was the highest, significantly higher than that of $\mathrm{W} 1 \mathrm{~N} 2$, the rest of the treatments was not significantly different from W1N1. In early season, the PDH activity of W2N2 treatment in 'Nongxiang 18' was the highest, significantly higher than that of W1N1 and W1N2, W2N1 was not significantly different from W2N2. The OAT activity of W2N1 treatment in 'Nongxiang 18' was the highest, significantly higher than that of $\mathrm{W} 1 \mathrm{~N} 1$, the rest of the treatments was not significantly different from $\mathrm{W} 2 \mathrm{~N} 1$.

\section{Proline content and activities of enzymes involved in 2-AP biosynthesis in leaves}

For Basmati 385, the P5C content in leaves was $23.77 \%$ higher in $\mathrm{W} 2$ than $\mathrm{W} 1$ during early season whereas the activity of PDH was recorded $5.54 \%$ higher in $\mathrm{N} 1$ than $\mathrm{N} 2$ during early season. Regarding interaction, the $\mathrm{W} 2 \mathrm{~N} 1$ had led to noticeable improvements in PDH, OAT, P5CS activities and P5C content during early season. In late season, W2 treatment increased the proline content, OAT activity and P5CS activity by $26.31 \%, 6.33 \%$ and $27.43 \%$ as compared to $\mathrm{W} 1$, respectively. The proline content in N1treatment showed $19.31 \%$ higher than in N2 treatment. The proline and P5C contents as well as the activities of PDH, OAT, and P5CS during late season were improved under W2N1 interaction. However, the activity of OAT under N1 was 3.06\% lower than $\mathrm{N} 2$ during late season.

For Nongxiang18, W2 treatment showed $3.70 \%$ and $16.54 \%$ higher proline and P5C contents, respectively than $\mathrm{W} 1$ in early season whilst $7.35 \%$ and $13.18 \%$ higher proline and P5C contents were recorded under N1 than N2 application in early season. Moreover, significant improvements were observed in proline and P5C contents during early season under W2N1 interaction. During late season, PDH, OAT, and P5CS activities and P5C content were 5.98\%, 8.45\%, 20.82\%, and 13.04\% lower under N1 than $\mathrm{N} 2$ treatment. Additionally, W2N1 enhanced the activities of PDH and OAT (Table 4).

The proline content and PDH, OAT, and P5CS (except W2N2 treatment) activities of 'Basmati 385' in early season were higher than that in late season. The proline content of 'Nongxiang 18' in early season was higher than that in late season. In late season, the P5C content (except W2N1 treatment) of 'Basmati 385' and PDH (except W1N1 treatment), OAT (except W1N1 treatment ) activities of 'Nongxiang 18' were higher than that of the early season.

For 'Basmati 385', in early season the proline content (except W2N1 treatment) and PDH (except W1N1 treatment), OAT (except W1N1 treatment), and P5CS activities in early season were higher than that in 'Nongxiang 18', and P5CS activity in late season were higher than that in 'Nongxiang 18'. For 'Nongxiang 18', the proline content (except W2N1 treatment), PDH, OAT activities in late season were higher than that in 'Basmati 385'.

In early season, the PDH, OAT, and P5CS activities and P5C content of W2N1 treatment in 'Basmati 385' were the highest, significantly higher than W2N2 (PDH activity), W2N2 and W1N1 (OAT activity), W1N1(P5CS activity), W1N1 and W1N2 (P5C content), however, the rest were found statistically similar $(\mathrm{P}>0.05)$ with W2N1. In late season, the proline content, PDH activity and OAT activity of W2N1 treatment in 'Basmati 385' were the highest, significantly higher than that of W1N1 and W1N2 (proline content), the rest of the treatments (PDH activity), W1N1(OAT activity), the rest was not significantly different from W2N1. The P5CS activity and P5C content of 'Basmati 385' under W2N2 treatment were the highest, significantly higher than that of $\mathrm{W} 1 \mathrm{~N} 1$ and $\mathrm{W} 1 \mathrm{~N} 2$ (P5CS activity), W1N1(P5C content), the rest of the treatments was 
not significantly different from W2N2. In early season, the proline and P5C contents of 'Nongxiang 18' under W2N1 treatment were the highest, significantly higher than that of the rest of the treatments. The proline content under W1N2 was significantly higher than that of W2N2, W1N1 has no significant difference with the above two treatments. In late season, the PDH, OAT activities and P5C content of 'Nongxiang 18' under $\mathrm{W} 1 \mathrm{~N} 2$ treatment were the highest, significantly higher than that of W1N1 (PDH activity and OAT activity), W1N1 and $\mathrm{W} 2 \mathrm{~N} 1(\mathrm{P} 5 \mathrm{C}$ content), the rest was not significantly different from W1N2. The P5CS activity of 'Nongxiang 18' under W2N2 treatment was the highest, significantly higher than that of $\mathrm{W} 1 \mathrm{~N} 1$ and $\mathrm{W} 2 \mathrm{~N} 1, \mathrm{~W} 1 \mathrm{~N} 1$ had no significant difference from other treatments.

Table 4. Effect of mild drought and nitrogen on proline, protein and enzymes involved in 2AP biosynthesis in the leaves of fragrant rice

\begin{tabular}{|c|c|c|c|c|c|c|c|c|c|c|}
\hline \multirow[b]{2}{*}{ 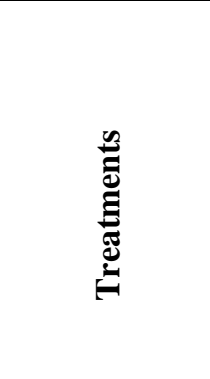 } & \multicolumn{5}{|c|}{ Early season } & \multicolumn{5}{|c|}{ Late season } \\
\hline & 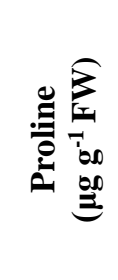 & 吝 & 点 & 说 & 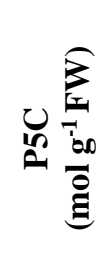 & & 吝 & 音 & 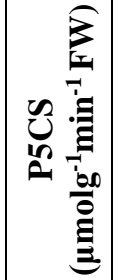 & مَ' \\
\hline Basmati 385 & & & & & & & & & & \\
\hline W1 & $11.36 \mathrm{a}$ & $36.95 \mathrm{a}$ & $27.34 \mathrm{a}$ & $4.62 \mathrm{a}$ & $1.22 \mathrm{~b}$ & $7.83 b$ & $35.08 \mathrm{a}$ & $26.24 b$ & $3.39 b$ & $1.34 \mathrm{a}$ \\
\hline W2 & $12.08 \mathrm{a}$ & $38.79 a$ & $29.00 \mathrm{a}$ & $5.61 \mathrm{a}$ & $1.51 \mathrm{a}$ & 9.89a & $36.67 \mathrm{a}$ & $27.90 \mathrm{a}$ & $4.32 \mathrm{a}$ & $1.54 \mathrm{a}$ \\
\hline $\mathrm{N} 1$ & $11.81 \mathrm{a}$ & $38.89 \mathrm{a}$ & $28.28 \mathrm{a}$ & $5.10 \mathrm{a}$ & $1.33 \mathrm{a}$ & $9.64 \mathrm{a}$ & $36.45 a$ & $26.65 b$ & 3.66a & $1.37 \mathrm{a}$ \\
\hline $\mathrm{N} 2$ & $11.63 \mathrm{a}$ & $36.85 b$ & $28.06 \mathrm{a}$ & $5.12 \mathrm{a}$ & $1.40 \mathrm{a}$ & $8.08 \mathrm{~b}$ & $35.31 \mathrm{a}$ & $27.49 \mathrm{a}$ & $4.05 \mathrm{a}$ & $1.51 \mathrm{a}$ \\
\hline W1N1 & $11.28 \mathrm{a}$ & $37.04 \mathrm{ab}$ & $26.03 c$ & $4.05 b$ & $1.13 \mathrm{c}$ & $8.82 b$ & $35.33 b$ & $25.31 \mathrm{~b}$ & $3.25 \mathrm{~b}$ & $1.25 \mathrm{~b}$ \\
\hline $\mathrm{W} 1 \mathrm{~N} 2$ & $11.44 \mathrm{a}$ & $36.87 \mathrm{ab}$ & 28.66ab & $5.19 \mathrm{ab}$ & $1.30 \mathrm{bc}$ & $6.84 \mathrm{c}$ & $34.83 b$ & $27.17 \mathrm{a}$ & $3.52 b$ & $1.43 \mathrm{ab}$ \\
\hline W2N1 & $12.33 \mathrm{a}$ & $40.75 \mathrm{a}$ & $30.52 \mathrm{a}$ & $6.15 \mathrm{a}$ & $1.53 \mathrm{a}$ & $10.46 \mathrm{a}$ & $37.56 \mathrm{a}$ & $27.99 \mathrm{a}$ & $4.07 \mathrm{ab}$ & $1.49 \mathrm{ab}$ \\
\hline W2N2 & $11.82 \mathrm{a}$ & $36.83 b$ & $27.47 \mathrm{bc}$ & $5.06 \mathrm{ab}$ & $1.49 \mathrm{ab}$ & $9.33 \mathrm{ab}$ & $35.79 \mathrm{~b}$ & $27.82 \mathrm{a}$ & $4.58 \mathrm{a}$ & $1.60 \mathrm{a}$ \\
\hline Nongxiang 18 & & & & & & & & & & \\
\hline W1 & $11.07 \mathrm{~b}$ & $36.61 \mathrm{a}$ & $27.70 \mathrm{a}$ & $3.58 \mathrm{a}$ & $1.27 \mathrm{~b}$ & $9.53 \mathrm{a}$ & $38.12 \mathrm{a}$ & $28.50 \mathrm{a}$ & $3.26 \mathrm{a}$ & $1.51 \mathrm{a}$ \\
\hline W2 & $11.48 \mathrm{a}$ & $35.71 \mathrm{a}$ & $27.84 \mathrm{a}$ & $4.12 \mathrm{a}$ & $1.48 \mathrm{a}$ & $9.67 \mathrm{a}$ & $40.09 \mathrm{a}$ & $29.08 \mathrm{a}$ & $3.70 \mathrm{a}$ & $1.50 \mathrm{a}$ \\
\hline $\mathrm{N} 1$ & $11.68 \mathrm{a}$ & $36.35 \mathrm{a}$ & $28.15 \mathrm{a}$ & $4.05 \mathrm{a}$ & $1.46 \mathrm{a}$ & $9.75 \mathrm{a}$ & $37.90 \mathrm{~b}$ & $27.52 b$ & $3.08 \mathrm{~b}$ & $1.40 \mathrm{~b}$ \\
\hline $\mathrm{N} 2$ & $10.88 b$ & $35.97 \mathrm{a}$ & $27.38 \mathrm{a}$ & $3.65 \mathrm{a}$ & $1.29 b$ & $9.45 \mathrm{a}$ & $40.31 \mathrm{a}$ & $30.06 \mathrm{a}$ & $3.89 \mathrm{a}$ & $1.61 \mathrm{a}$ \\
\hline $\mathrm{W} 1 \mathrm{~N} 1$ & $10.89 b c$ & $37.54 \mathrm{a}$ & $27.61 \mathrm{a}$ & $3.59 \mathrm{a}$ & $1.37 \mathrm{~b}$ & $9.70 \mathrm{a}$ & $36.15 b$ & $25.45 \mathrm{~b}$ & $3.05 b$ & $1.34 \mathrm{c}$ \\
\hline $\mathrm{W} 1 \mathrm{~N} 2$ & $11.25 \mathrm{~b}$ & $35.67 \mathrm{a}$ & $27.79 \mathrm{a}$ & $3.57 \mathrm{a}$ & $1.18 \mathrm{c}$ & $9.36 \mathrm{a}$ & $40.09 a$ & $31.55 \mathrm{a}$ & $3.47 \mathrm{ab}$ & $1.67 \mathrm{a}$ \\
\hline $\mathrm{W} 2 \mathrm{~N} 1$ & $12.46 \mathrm{a}$ & $35.15 \mathrm{a}$ & $28.70 \mathrm{a}$ & $4.51 \mathrm{a}$ & $1.55 \mathrm{a}$ & $9.79 \mathrm{a}$ & $39.65 \mathrm{ab}$ & $29.60 \mathrm{ab}$ & $3.10 \mathrm{~b}$ & $1.46 \mathrm{bc}$ \\
\hline W2N2 & $10.50 \mathrm{c}$ & $36.26 a$ & $26.97 \mathrm{a}$ & $3.73 \mathrm{a}$ & $1.40 \mathrm{~b}$ & $9.55 \mathrm{a}$ & $40.54 \mathrm{a}$ & 28.56ab & $4.30 \mathrm{a}$ & $1.54 \mathrm{ab}$ \\
\hline
\end{tabular}

Means with different lower-case letter in the same column for the same variety under the same treatments show significant difference at $\mathrm{P}=0.05$ by LSD tests. W1: well-watered $(4-6 \mathrm{~cm}$ water layer, W2: moderate drought, soil water potential $(-25 \pm 5 \mathrm{kPa})$; $\mathrm{N} 1: 15 \mathrm{~kg} \mathrm{~N} \mathrm{hm}^{-2}, \mathrm{~N} 2: 30 \mathrm{~kg} \mathrm{~N} \mathrm{hm}^{-2}$. PDH: Proline dehydrogenase; OAT: ornithine aminotransferase; P5CS: $\Delta^{1}$ - pyrroline-5-carboxylic acid synthetase; P5C: $\Delta^{1}$-pyrroline-5-carboxylic acid 


\section{Yield and yield components}

Both mild drought conditions and additional $\mathrm{N}$ application affected yield and related traits of both rice cultivars during both seasons. For instance, during early season, N1 showed $1.64 \%$ higher 1000 -grain weight than N2 for 'Basmati 385' whilst the 1000grain weight under W2 was $3.20 \%$ lower than under W1. During early season, both rice cultivars were remained statistically similar $(\mathrm{p}>0.05)$ for grain yield under all treatments. During late season, the highest yield was observed in W2N1 treatment in 'Basmati 385' (7.39 t hm$\left.{ }^{-2}\right)$ and 'Nongxiang18' $\left(8.07 \mathrm{t} \mathrm{hm}^{-2}\right)$. Moreover, for 'Nongxiang 18 ', the W2 treatment significantly increased grain yield by $4.39 \%$ than $\mathrm{W} 1$ treatment (Table 5).

Table 5. Effect of mild drought and nitrogen on yield and yield components of fragrant rice

\begin{tabular}{|c|c|c|c|c|c|c|c|c|c|c|}
\hline \multicolumn{6}{|c|}{ Early season } & \multicolumn{5}{|c|}{ Late season } \\
\hline 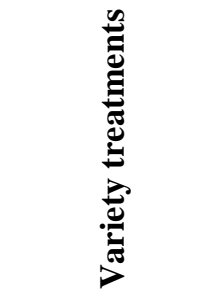 & 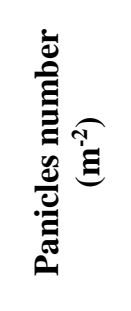 & 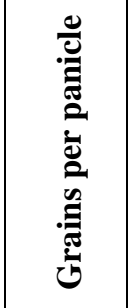 & 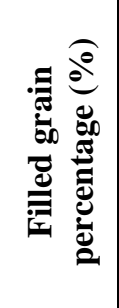 & 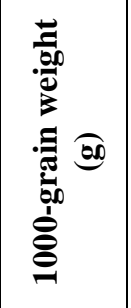 & 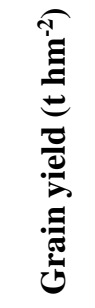 & 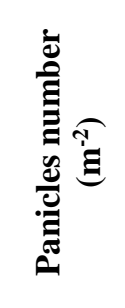 & 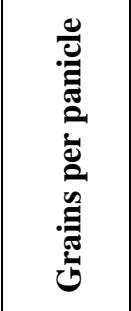 & 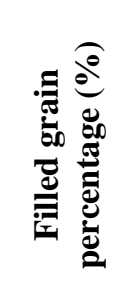 & 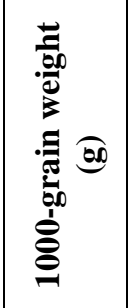 & 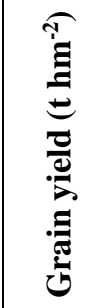 \\
\hline \multicolumn{11}{|l|}{ Basmati 385} \\
\hline W1 & $238.48 \mathrm{a}$ & $131.55 \mathrm{a}$ & $77.69 \mathrm{a}$ & $25.59 \mathrm{a}$ & $5.24 \mathrm{a}$ & $241.54 \mathrm{a}$ & $131.04 \mathrm{a}$ & $92.01 \mathrm{a}$ & $27.61 \mathrm{a}$ & $6.56 \mathrm{a}$ \\
\hline W2 & $232.61 \mathrm{a}$ & $135.18 \mathrm{a}$ & $75.56 \mathrm{a}$ & $24.77 \mathrm{~b}$ & $5.27 \mathrm{a}$ & $238.38 \mathrm{a}$ & $121.03 \mathrm{a}$ & $88.90 \mathrm{a}$ & $27.62 \mathrm{a}$ & $6.95 \mathrm{a}$ \\
\hline N1 & $236.20 \mathrm{a}$ & $136.24 \mathrm{a}$ & $76.87 \mathrm{a}$ & $25.39 \mathrm{a}$ & $5.30 \mathrm{a}$ & $230.25 a$ & $129.93 a$ & $91.21 \mathrm{a}$ & $27.30 \mathrm{a}$ & 6.91a \\
\hline N2 & $234.88 \mathrm{a}$ & $130.49 \mathrm{a}$ & $76.38 \mathrm{a}$ & $24.98 \mathrm{~b}$ & $5.22 \mathrm{a}$ & $249.67 \mathrm{a}$ & $122.14 \mathrm{a}$ & $89.70 \mathrm{a}$ & $27.92 \mathrm{a}$ & $6.60 \mathrm{a}$ \\
\hline W1N1 & $234.44 a$ & $137.52 \mathrm{a}$ & $76.22 \mathrm{a}$ & $25.10 \mathrm{c}$ & $5.56 a$ & $230.83 a$ & $141.08 \mathrm{a}$ & $92.91 \mathrm{a}$ & $27.37 \mathrm{a}$ & $6.43 b$ \\
\hline W1N2 & $242.51 \mathrm{a}$ & $125.58 \mathrm{a}$ & $79.15 \mathrm{a}$ & $26.09 \mathrm{a}$ & $4.92 \mathrm{a}$ & $252.25 \mathrm{a}$ & $120.99 a$ & $91.11 \mathrm{a}$ & $27.85 \mathrm{a}$ & $6.70 \mathrm{~b}$ \\
\hline W2N1 & $237.96 a$ & $134.96 \mathrm{a}$ & $77.51 \mathrm{a}$ & $25.68 b$ & $5.03 \mathrm{a}$ & $229.67 \mathrm{a}$ & $118.79 \mathrm{a}$ & $89.51 \mathrm{a}$ & $27.24 \mathrm{a}$ & 7.39a \\
\hline $\mathrm{W} 2 \mathrm{~N} 2$ & $227.25 a$ & $135.41 \mathrm{a}$ & 73.61a & $23.86 \mathrm{~d}$ & $5.51 \mathrm{a}$ & $247.08 \mathrm{a}$ & $123.28 \mathrm{a}$ & $88.28 \mathrm{a}$ & $28.00 \mathrm{a}$ & $6.51 b$ \\
\hline \multicolumn{11}{|l|}{ Nongxiang 18} \\
\hline $\mathrm{W} 1$ & $239.52 a$ & $134.92 \mathrm{a}$ & $67.08 \mathrm{a}$ & $25.53 \mathrm{a}$ & $4.76 a$ & $243.33 a$ & $118.58 \mathrm{a}$ & $90.83 a$ & $24.81 \mathrm{~b}$ & $7.51 \mathrm{~b}$ \\
\hline $\mathrm{W} 2$ & $238.72 a$ & $143.29 \mathrm{a}$ & $74.12 \mathrm{a}$ & $24.98 \mathrm{a}$ & $5.24 \mathrm{a}$ & $248.54 a$ & $125.68 \mathrm{a}$ & $89.58 \mathrm{a}$ & $25.82 \mathrm{a}$ & $7.84 \mathrm{a}$ \\
\hline N1 & $236.58 \mathrm{a}$ & $135.75 \mathrm{a}$ & $71.29 \mathrm{a}$ & $25.17 \mathrm{a}$ & $4.69 a$ & $243.13 \mathrm{a}$ & $124.91 \mathrm{a}$ & $91.35 \mathrm{a}$ & $25.42 \mathrm{a}$ & $7.75 \mathrm{a}$ \\
\hline $\mathrm{N} 2$ & $241.67 \mathrm{a}$ & $142.45 \mathrm{a}$ & $69.91 \mathrm{a}$ & $25.34 \mathrm{a}$ & $5.31 \mathrm{a}$ & $248.75 a$ & $119.35 a$ & $89.05 a$ & $25.21 \mathrm{a}$ & 7.60a \\
\hline W1N1 & $236.67 \mathrm{a}$ & $124.90 \mathrm{a}$ & $68.63 \mathrm{a}$ & $25.27 \mathrm{ab}$ & $4.31 \mathrm{a}$ & $246.67 \mathrm{a}$ & $119.75 a$ & $94.48 \mathrm{a}$ & $25.32 \mathrm{ab}$ & $7.43 b$ \\
\hline W1N2 & $242.38 \mathrm{a}$ & $144.93 \mathrm{a}$ & $65.53 \mathrm{a}$ & $25.78 \mathrm{a}$ & $5.21 \mathrm{a}$ & $240.00 \mathrm{a}$ & $117.40 \mathrm{a}$ & $87.17 b$ & $24.30 \mathrm{~b}$ & $7.59 \mathrm{~b}$ \\
\hline W2N1 & $236.49 a$ & $146.61 \mathrm{a}$ & $73.95 \mathrm{a}$ & $25.06 \mathrm{ab}$ & $5.08 \mathrm{a}$ & $239.58 \mathrm{a}$ & $130.07 \mathrm{a}$ & $88.22 b$ & $25.52 \mathrm{ab}$ & $8.07 \mathrm{a}$ \\
\hline W2N2 & $240.95 a$ & $139.97 \mathrm{a}$ & $74.30 \mathrm{a}$ & $24.89 \mathrm{~b}$ & $5.40 \mathrm{a}$ & $257.50 \mathrm{a}$ & $121.29 \mathrm{a}$ & $90.93 \mathrm{ab}$ & $26.12 \mathrm{a}$ & 7.61ab \\
\hline
\end{tabular}

Means with different lower-case letter in the same column for the same variety under the same treatments show significant difference at $\mathrm{P}=0.05$ by LSD tests. W1: well-watered $(4-6 \mathrm{~cm}$ water layer, W2: moderate drought, soil water potential $(-25 \pm 5 \mathrm{kPa}) ; \mathrm{N} 1: 15 \mathrm{~kg} \mathrm{~N} \mathrm{hm}^{-2}, \mathrm{~N} 2: 30 \mathrm{~kg} \mathrm{~N} \mathrm{hm}^{-2}$

The grains per panicle of 'Basmati 385' and 'Nongxiang 18' in early season were higher than that in late season except for 'Basmati 385' under W1N1 treatment. In late season, the filled grain percentage, 1000-grain weight and grain yield of the treatments 
of 'Basmati 385' and 'Nongxiang 18' were higher than that of the early season, except for the 1000-grain weight in 'Nongxiang 18' for W1N2 treatment. The panicles number of 'Nongxiang 18' in late season was higher than that in early season except W1N2.

For 'Basmati 385', the filled grain percentage (except W2N2 treatment) in early season and grains per panicle (except W2N1 treatment) in late season were higher than that in 'Nongxiang 18'. For 'Nongxiang 18', in early season the grains per panicle (except $\mathrm{W} 1 \mathrm{~N} 1$ treatment) and in late season panicles number per $\mathrm{m}^{2}$ (except W1N2 treatment) and grain yield in early season were higher than that in 'Basmati 385'.

In early season, the 1000-grain weight of W1N2 treatment in 'Basmati 385' was the highest, significantly higher than that of $\mathrm{W} 2 \mathrm{~N} 1$, and $\mathrm{W} 2 \mathrm{~N} 1$ was also significantly higher than that of W1N1, and the smallest was W2N2. In the early season, the 1000grain weight of W1N2 in 'Nongxiang18' was significantly higher than W2N2, the trend for the water and $\mathrm{N}$ interaction treatments is as follow: $\mathrm{W} 1 \mathrm{~N} 2>\mathrm{W} 1 \mathrm{~N} 1>\mathrm{W} 2 \mathrm{~N} 1>\mathrm{W} 2 \mathrm{~N} 2$.

In the late season, the filled grain percentage of 'Nongxiang 18 ' in the late season was the highest in W1N1, which was significantly higher than W1N2 and W2N1, and the difference was not significant with W2N2. The 1000-grain weight of W2N2 treatment in 'Nongxiang 18' was significantly higher than W1N2, the trend for the water and $\mathrm{N}$ interaction treatments is as follow: W2N2> W2N1>W1N1>W1N2. In late season, 'Basmati 385' had the highest yield under W2N1 treatment, which was significantly higher than that of other treatments. In late season, 'Nongxiang 18' had the highest yield under W2N1 treatment, which was significantly higher than that of W1N1 and $\mathrm{W} 1 \mathrm{~N} 2$ treatments.

\section{Relationships among 2-AP, proline and enzymes involved in 2-AP biosynthesis}

2-AP content in brown rice showed positive correlations with PDH activity in grains whilst negative correlations with proline content in grains in both seasons. Moreover, significantly positive correlations were observed between proline content and OAT activity in grains. For late season, 2-AP content in brown rice showed significant and positive correlation with PDH activity in grains (Table 6).

2-AP content in brown rice showed positive correlation with proline content in leaves in both seasons. For early season, PDH activity in leaves showed significant but negative correlation with $\mathrm{P} 5 \mathrm{C}$ content in leaves whereas for late season, significant and positive correlation was observed between PDH activity and OAT activity in leaves. Additionally, OAT activity in leaves showed significantly positive correlation with P5CS activity in leaves (Table 7).

\section{Discussion}

Volatile chemistry and aroma biosynthesis are intricate phenomena that are genetically controlled, but external environmental conditions, crop nutrition and cultivation/management practices could also regulate the aroma biosynthesis in fragrant rice. Effects of mild drought stress and $\mathrm{N}$ application on 2-AP content, enzymes involved in its biosynthesis and yield attributes were studied in two fragrant rice cultivars. Mild drought conditions at grain filling stage could improve the 2-AP content in fragrant rice; however the $\mathrm{W}$ and $\mathrm{N}$ treatments had not obvious effects on grain 2-AP content during early season (Table 2) which may be related to the regional prevailing climatic conditions (Fig. 1). Mild drought stress (soil water potential: $-25 \pm 5 \mathrm{kPa}$ ) at tillering and booting stage in fragrant rice enhanced 2-AP content in brown rice $30 \%$ 
and 47\%, respectively (Wang et al., 2013a, b). Moreover, alternate wetting and drying at grain filling stage markedly enhanced the brown rice 2-AP content in fragrant rice (Tian et al., 2014). Regarding nitrogen application, N1 treatment significantly increased the 2-AP content in both cultivars, whereas the highest 2-AP content of both cultivars was observed in W2N1 treatment. Mild drought conditions could enhance the biosynthesis of cytosolic proline concentration which not only involved in osmoregulation (Ashraf and Fooland, 2007; Anjum et al., 2011) but also have associations with 2-AP or aroma formation in fragrant rice (Yoshihashi et al., 2002). Previously, Yang et al. (2012) reported that higher proline content in fragrant rice corresponds to higher soil and plant $\mathrm{N}$ status, which on the other hand, associated with the stronger aroma. Availability of $\mathrm{N}$ in inorganic forms i.e., $\mathrm{NO}^{3-}$ and $\mathrm{NH}^{4+}$ also regulates the proline biosynthesis in plants (Delauney and Verma, 1993).

Table 6. Relationships among 2-AP, proline and enzymes involved in 2-AP biosynthesis in the gains of fragrant rice

\begin{tabular}{c|c|c|c|c|c|c}
\hline & Grain 2-AP & $\begin{array}{c}\text { Proline } \\
\text { content }\end{array}$ & $\begin{array}{c}\text { PDH } \\
\text { activity }\end{array}$ & $\begin{array}{c}\text { OAT } \\
\text { activity }\end{array}$ & $\begin{array}{c}\text { P5C } \\
\text { content }\end{array}$ & $\begin{array}{c}\text { P5CS } \\
\text { activity }\end{array}$ \\
\hline $\begin{array}{c}\text { Early season } \\
\text { Grain 2-AP content }\end{array}$ & 1 & & & & & \\
proline content & $-0.7178^{*}$ & 1 & & & & \\
PDH activity & 0.4922 & 0.0688 & 1 & & & \\
OAT activity & -0.2239 & $0.7724^{*}$ & 0.3071 & 1 & & \\
P5C & -0.2523 & 0.3086 & -0.1516 & 0.5805 & 1 & \\
P5CS activity & 0.1858 & 0.2694 & 0.5916 & 0.6717 & 0.6306 & 1 \\
Late season & & & & & & \\
Grain 2-AP content & 1 & & & & & \\
proline content & -0.4434 & 1 & & & & \\
PDH activity & $0.8037 *$ & -0.3337 & 1 & & & \\
OAT activity & 0.1000 & 0.4167 & 0.2412 & 1 & & \\
P5C & 0.1796 & -0.3489 & 0.5431 & -0.2854 & 1 & \\
P5CS activity & -0.3617 & 0.5756 & -0.2124 & $0.7105^{*}$ & -0.6272 & 1 \\
\hline
\end{tabular}

*Significant at $\mathrm{P}<0.05$; **Significant at $\mathrm{P}<0.01$. PDH: Proline dehydrogenase; OAT: ornithine aminotransferase; P5CS: $\Delta^{1}$-pyrroline-5-carboxylic acid synthetase; P5C: $\Delta^{1}$-pyrroline-5-carboxylic acids

Enzymes involved in 2-AP biosynthesis are influenced by water-nitrogen treatments (Tables 3 and 4) whereas the formation of 2-AP is largely associated with brown rice 2AP content (Table 6). Generally, proline, glutamic acid, and ornithine are the important precursors of 2-AP formation in fragrant rice (Wu et al., 2009). The PDH, OAT, and P5CS enzymes are directly involved in the conversion of proline, ornithine, and glutamic acid (the precursors of 2-AP) into $\Delta^{1}$-pyrroline-5-carboxylic acid (Huang et al., 2008; Li et al., 2016) which is later converted into 2-AP by enzymatic (Acyl Co-A group) and non-enzymatic (methylglyoxal) pathways (Wongpia et al., 2016). Besides, conversion of ornithine $\rightarrow$ putrescine $\rightarrow \gamma$-aminobutyl aldehyde (GABald) $\rightarrow \triangle^{1}$ pyrroline $\rightarrow 2$-AP is the other way of 2-AP formation (Bradbury et al., 2008; Chen et al., 2008; Fitzgerald et al., 2010; Hashemi et al., 2013). Later, Huang et al. (2008) also found positive associations between $\mathrm{P} 5 \mathrm{C}$ and 2-AP content in both fragrant and non- 
fragrant rice. Furthermore, Mo et al. (2016) suggested that the proline and 2-AP in leaves might be transported to grains, affecting the concentration of 2-AP in grains. The W2N1 treatment increased the proline content in leaves and the activities of most enzymes involved in 2-AP biosynthesis of both cultivars, thus improved final 2-AP content in brown rice. Strong aroma in fragrant rice was observed under stress conditions (Fitzgerald et al., 2010; Gay et al., 2010) and plant mineral nutrition (Tang and Wu 2006; Lei et al., 2017).

Table 7. Relationships among 2-AP, proline and enzymes involved in 2-AP biosynthesis in the leaves of fragrant rice

\begin{tabular}{c|c|c|c|c|c|c}
\hline & Grain 2-AP & $\begin{array}{c}\text { Proline } \\
\text { content }\end{array}$ & $\begin{array}{c}\text { PDH } \\
\text { activity }\end{array}$ & $\begin{array}{c}\text { OAT } \\
\text { activity }\end{array}$ & $\begin{array}{c}\text { P5C } \\
\text { content }\end{array}$ & $\begin{array}{c}\text { P5CS } \\
\text { activity }\end{array}$ \\
\hline Early season & & & & & & \\
Grain 2-AP content & 1 & & & & & \\
proline content & 0.4705 & 1 & & & & \\
PDH activity & 0.2175 & 0.2522 & 1 & & & \\
OAT activity & 0.2513 & 0.6761 & 0.5577 & 1 & & \\
P5C & -0.2523 & -0.3704 & $-0.7360^{*}$ & -0.2899 & 1 & \\
P5CS activity & 0.1208 & 0.5643 & 0.2562 & 0.6101 & -0.5415 & 1 \\
Late season & & & & & & \\
Grain 2-AP content & 1 & & & & & \\
proline content & 0.2189 & 1 & & & & \\
PDH activity & -0.4034 & 0.5232 & 1 & & & \\
OAT activity & -0.1987 & 0.2188 & $0.7841^{*}$ & 1 & & \\
P5C & 0.1796 & -0.4842 & -0.6307 & -0.2632 & 1 & \\
P5CS activity & -0.0505 & 0.2010 & 0.5697 & $0.8486^{* *}$ & 0.1631 & 1 \\
\hline
\end{tabular}

*Significant at $\mathrm{P}<0.05$; **Significant at $\mathrm{P}<0.01$. PDH: Proline dehydrogenase; OAT: ornithine aminotransferase; P5CS: $\Delta^{1}$-pyrroline-5-carboxylic acid synthetase; P5C: $\Delta^{1}$-pyrroline-5-carboxylic acid

In this study, the grain yield was found higher in $\mathrm{W} 2 \mathrm{~N} 1$ treatment in both the rice cultivars (Table 5) that corroborates with the previous findings. For instance, $\mathrm{Li}$ et al. (2008) found the combination of mild soil drying (soil water potential: $-25 \mathrm{kPa}$ ) and $\mathrm{N}$ application at $45 \mathrm{~kg} \mathrm{hm}^{-2}$ at grain filling stage can improve grain yield and quality in rice together. Chen et al. (2004) found the supplementation of $4 \mathrm{~g}$ urea per pot under mild water stress $(-25 \mathrm{kPa})$ during grain filling stage could increase rice yield significantly. Moreover $2 \mathrm{~g}$ urea application coupled with moderate water stress $(-30$ $\mathrm{kPa}$ ) led to appreciable increase in 1000-grain weight and final grain yield in rice (Cai et al., 2006). Hence, application of additional $\mathrm{N}$ dose and mild drought conditions at grain filling stage could induce the strong aroma in fragrant rice whilst exact role of $\mathrm{N}$ and $\mathrm{N}$ metabolism in aroma regulations is still need to be explored.

\section{Conclusion}

Mild drought stress $(-25 \pm 5 \mathrm{kPa})$ in interaction with nitrogen supplementation at $15 \mathrm{~kg} \mathrm{hm}^{-2}$ could enhance the grain 2-AP content and activities of enzymes involved in its biosynthesis in fragrant rice. Under W2N1 interaction, the 2-AP content in both rice 
cultivars was enhanced and provided higher yields. The 2-AP content in brown rice showed significantly negative correlation with proline for early season, but significant and positive correlation with PDH activity in grains for late season. Hence, water and N induced regulations in 2-AP biosynthesis are obvious but the exact mechanism lies behind these factors that reinforce the aroma regulations; further research at physiological and molecular level is needed. This study explored the management measures of water and nitrogen during grain filling stage for aromatic rice with improved 2-AP content and high yield, it provided theoretical basis for high yield and increasing aroma cultivation of aromatic rice.

Acknowledgements. We acknowledge the funding provided by National Natural Science Foundation of China (31271646), Special Fund for National Natural Science Foundation for Young Scientists (31601244)

\section{REFERENCES}

[1] Anjum, S. A., Wang, L. C., Farooq, M., Hussain, M., Xue, L. L., Zou, C. M. (2011): Brassinolide application improves the drought tolerance in maize through modulation of enzymatic antioxidants and leaf gas exchange. - Journal of Agronomy and Crop Science 197(3): 177-185.

[2] Ashraf, M., Foolad, M. (2007): Roles of glycine betaine and proline in improving plant abiotic stress resistance. - Environmental and Experimental Botany 59(2): 206-216.

[3] Ashraf, U., Tang, X. R. (2017a): Yield and quality responses, plant metabolism and metal distribution pattern in aromatic rice under lead $(\mathrm{Pb})$ toxicity. - Chemosphere 176: 141-55.

[4] Ashraf, U., Kanu, A. S., Deng, Q. Q., Mo, Z. W., Pan, S. G., Tian, H., Tang, X. R. (2017b): Lead $(\mathrm{Pb})$ toxicity; physio-biochemical mechanisms, grain yield, quality, and $\mathrm{Pb}$ distribution proportions in scented rice. - Frontiers in Plant Science 8: 1-17.

[5] Ashraf, U., Hussain, S., Anjum, S. A., Abbas, F., Tanveer, M., Noor , M. A., Tang, X. R. (2017c): Alterations in growth, oxidative damage, and metal uptake of five aromatic rice cultivars under lead toxicity. - Plant Physiology and Biochemistry 115: 461-471.

[6] Bates, L. S., Waldren, R. P., Teare, I. D. (1973): Rapid determination of free proline for water-stress studies. - Plant and Soil 39(1): 205-207.

[7] Bhattacharjee, P., Singhal, R.S, Kulkarni, P. R. (2002): Basmati rice: a review. International Journal of Food Science \& Technology 37: 1-12.

[8] Bradbury, L. M., Henry, R. J., Jin, Q., Reinke, R. F., Waters, D. L. (2005a): A perfect marker for fragrance genotyping in rice. - Molecular Breeding 16(4): 279-283.

[9] Bradbury, L. M., Fitzgerald, T. L., Henry, R. J., Jin, Q., Waters, D. L. (2005b): The gene for fragrance in rice. - Plant Biotechnology Journal 3(3): 363-370.

[10] Bradbury, L. M., Gillies, S. A., Brushett, D. J., Waters, D. L., Henry, R. J. (2008): Inactivation of an aminoaldehyde dehydrogenase is responsible for fragrance in rice. Plant Molecular Biology 68(4-5): 439-449.

[11] Bryant, R. J., McClung, A. M. (2011): Volatile profiles of aromatic and non-aromatic rice cultivars using SPME/GC-MS. - Food Chemistry 124(2): 501-513.

[12] Buttery, R. G., Ling, L. C., Juliano, B. O. (1982): 2-Acetyl-1-pyrroline: an important aroma component of cooked rice. - Chemistry and Industry 23: 958-959.

[13] Buttery, R. G., Ling, L. C., Juliano, B. O., Turnbaugh, J. G. (1983): Cooked rice aroma and 2-acetyl-1-pyrroline. - Journal of Agricultural and Food Chemistry 31(4): 823-826.

[14] Cabangon, R. J., Castillo, E. G., Tuong, T. P. (2011): Chlorophyll meter-based nitrogen management of rice grown under alternate wetting and drying irrigation. - Field Crops Research 121(1): 136-146. 
[15] Cai, Y. X., Wang, W., Zhu, Z. W., Zhang, Z. J., Lang, Y. Z., Zhu, Q. S. (2006): Effects of water stress during grain-filling period on rice grain yield and its quality under different nitrogen levels. - Chinese Journal of Applied Ecology 17(7): 1201-1206 (in Chinese).

[16] Cai, Y. X., Li, Y., Zhu, H. T., Cai, K. Z., Huang, F., Wang, W. (2015): Effects of deficit irrigation on the formation of the yield in rice (Oryza sativa) during filling period. Scientia Agricultura Sinica 48(8): 1492-1505 (in Chinese).

[17] Chen, C. T., Chen, L., Lin, C. C., Kao, C. H. (2001): Regulation of proline accumulation in detached rice leaves exposed to excess copper. - Plant Science 160(2): 283-290.

[18] Chen, S. H., Yang, Y., Shi, W. W., Ji, Q., He, F., Zhang, Z. D., Cheng, Z. K. (2008): Badh2, encoding betaine aldehyde dehydrogenase, inhibits the biosynthesis of 2-acetyl-1pyrroline, a major component in rice fragrance. - The Plant Cell 20(7): 1850-1861.

[19] Chen, X. H., Liu, K., Xu, G. W., Wang, Z. Q., Yang, J. C. (2004): Effects of nitrogen and soil moisture on photosynthetic characters of flag leaf, yield and quality during grain filling in rice. - Journal of Shanghai Jiaotong University (Agricultural Science) 22(1): 4853 (in Chinese).

[20] Delauney, A. J., Verma, D. P. S. (1993): Proline biosynthesis and osmoregulation in plants. - The Plant Journal 4(2): 215-223.

[21] Fitzgerald, T. L., Waters, D. L. E., Brooks,L. O., Henry, R. J. (2010): Fragrance in rice (Oryza sativa) is associated with reduced yield under salt treatment. - Environmental and Experimental Botany 68(3): 292-300.

[22] Gay, F., Maraval, I., Roques, S., Gunata, Z., Boulanger, R., Audebert, A.,Mestres, C. (2010): Effect of salinity on yield and 2-acetyl-1-pyrroline content in the grains of three fragrant rice cultivars (Oryza sativa L.) in Camargue (France). - Field Crops Research 117(1): 154-160.

[23] Haefele, S. M., Jabbar, S. M. A., Siopongco, J. D. L. C., Tirol-Padre, A., Amarante, S. T., Sta Cruz, P. C., Cosico, W. C. (2008): Nitrogen use efficiency in selected rice (Oryza sativa L.) genotypes under different water regimes and nitrogen levels. - Field Crops Research 107(2): 137-146.

[24] Hashemi, F. S. G., Rafii, M. Y., Ismail, M. R., Mahmud, T. M. M., Rahim, H. A., Asfaliza, R., Malek, M. A., Latif, M. A. (2013): Biochemical, genetic and molecular advances of fragrance characteristics in rice. - Critical Reviews in Plant Sciences 32(6): 445-457.

[25] Huang, T., Teng, C., Chang, J., Chuang, H., Ho, C., Wu, M. (2008): Biosynthetic mechanism of 2-acetyl-1-pyrroline and its relationship with $\Delta^{1}$-pyrroline-5-carboxylic acid and methylglyoxal in aromatic rice (Oryza sativa L.) callus. - Journal Of Agricultural and Food Chemistry 56(16): 7399-7404.

[26] Huang, Z. L., Tang, X. R., Wang, Y. L., Chen, M. J., Zhao, Z. K., Duan, M. Y. (2012): Effects of increasing aroma cultivation on aroma and grain yield of aromatic rice and their mechanism. - Scientia Agricultura Sinica 45(6): 1054-1065 (in Chinese)

[27] Kovach, M. J., Calingacion, M. N., Fitzgerald, M. A., McCouch, S. R. (2009): The origin and evolution of fragrance in rice (Oryza sativa L.). - Proceedings of the National Academy of Sciences 106(34): 14444-14449.

[28] Lei, S., Wang, C. C., Ashraf, U., Mo, Z. W., Nawaz, M., Ashraf, I., Muzaffar, W., Liu, S. J., Tang, X. R. (2017): Exogenous application of mixed micro-nutrients improves yield, quality, and 2-acetyl-1-pyrroline. - Applied Ecology and Environmental Research 15(3): 1097-1109.

[29] Li, G. S., Wang, Z. Q., Yuan, L. M., Liu, L. J., Yang, J. C. (2008): Coupling effects of soil moisture and nitrogen nutrient during grain filling on grain yield and quality of rice. Chinese Journal of Rice Science 22(2): 161-166 (in Chinese).

[30] Li, M. J., Ashraf, U., Tian, H., Mo, Z. W., Pan, S. G., Anjum, S. A., Duan, M. Y., Tang, X. R. (2016): Manganese-induced regulations in growth, yield formation, quality characters, rice aroma and enzyme involved in 2-acetyl-1-pyrroline biosynthesis in fragrant rice. - Plant Physiology and Biochemistry 103: 167-175. 
[31] Liu, L., Chen, T., Wang, Z., Zhang, H., Yang, J., Zhang, J. (2013): Combination of sitespecific nitrogen management and alternate wetting and drying irrigation increases grain yield and nitrogen and water use efficiency in super rice. - Field Crops Research 154: 226-235.

[32] Liu, L. J., Li, H. W., Zhao, B. H., Wang, Z. Q., Yang, J. C. (2012): Effects of alternate drying-wetting irrigation during grain filling on grain quality and its physiological mechanisms in rice. - Chinese Journal of Rice Science 26(1): 77-84 (in Chinese).

[33] Mo, Z. W., Li, W., Pan, S. G., Fitzgerald, T. L., Xiao, F., Tang, Y. J., Wang, Y. L.,Duan, M. Y.,Tian, H.,Tang, X. R. (2015): Shading during the grain filling period increases 2acetyl-1-pyrroline content in fragrant rice. - Rice 8(1): 1-10.

[34] Mo, Z. W., Huang, J., Xiao, D., Ashraf, U., Duan, M. Y., Pan, S. G. (2016): Supplementation of 2-AP, $\mathrm{Zn}$ and La improves 2-acetyl-1-pyrroline concentrations in detached aromatic rice panicles in vitro. - Plos One 11(2): 1-15.

[35] Myint, K. M., Arikit, S., Wanchana, S., Yoshihashi, T., Choowongkomon, K., Vanavichit, A. (2012): A PCR-based marker for a locus conferring the aroma in Myanmar rice (Oryza sativa L.). - The Oretical and Applied Genetics 125(5): 887-896.

[36] Ncube, B., Finnie, J.F, Van Staden, J. (2013): Dissecting the stress metabolic alterations in in vitro Cyrtanthus regenerants. - Plant Physiology and Biochemistry 65: 102-110.

[37] Pan, S. G., Cao, C. G., Cai, M. L., Wang, J. P., Wang, R. H., Zhai, J., Huang, S. Q. (2009): Effects of irrigation regime and nitrogen management on grain yield, quality and water productivity in rice. - Journal of Food Agriculture and Environment 7(2): 559-564.

[38] Ren, Y., Ashraf, U., He, L. X., Mo, Z. W., Wang, F., Wan, X. C., Kong, H., Ran, X. L., Tang, X. R. (2017): Irrigation and nitrogen management practices affect grain yield and 2-acetyl-1-pyrroline content in aromatic rice. - Applied Ecology and Environmental Research 15(4): 1447-1460.

[39] Sakthivel, K., Sundaram, R. M., Rani, N. S., Balachandran, S. M., Neeraja, C. N. (2009): Genetic and molecular basis of fragrance in rice. - Biotechnology Advances 27(4): 468473.

[40] Shi, W., Yang, Y., Chen, S., Xu, M. (2008): Discovery of a new fragrance allele and the development of functional markers for the breeding of fragrant rice varieties. - Molecular Breeding 22(2): 185-192.

[41] Tang, X. R., Wu, M. (2006): Effects of application of zinc, iron and lanthanum on contents of aroma in brown rice and proline in flag leaf of aromatic rice. - Hybrid Rice 21(6): 69-72 (in Chinese).

[42] Tian, H., Pan, S. G., Duan, M. Y., Chen, S. J., Tang, X. R. (2014): Effects of water treatment on aroma content, yield and quality of aromatic rice. - Journal of Irrigation Drainage 33(3): 130-132 (in Chinese).

[43] Wang, P., Tang, X. R., Tian, H., Pan, S. G., Duan, M. Y., Nie, J., Luo, Y. M.,Xiao, L. Z. (2013a): Effects of different irrigation modes on aroma content of aromatic rice at booting stage. - Guangdong Agricultural Sciences (8): 1-3 (in Chinese).

[44] Wang, P., Xiao, L. Z., Tang, X. R., Tian, H., Pan, S. G., Duan, M. Y., Nie, J., Luo, Y. M. (2013b): Effects of different irrigation modes on aroma content of aromatic rice at tillering stage. - Journal of Irrigation Drainage 32(1): 103-105 (in Chinese).

[45] Wongpanya, R., Boonyalai, N., Thammachuchourat, N., Horata, N., Arikit, S., Myint, K. M., Vanavichit, A., Choowongkomon, K. (2011): Biochemical and enzymatic study of rice BADH wild-type and mutants: an insight into fragrance in rice. - The Protein Journal 30(8): 529-538.

[46] Wongpia, A., Roytrakul, S., Nomura, M., Tajima, S.,Lomthaisong, K.,Mahatheeranont, S.,Niamsup, H. (2016): Proteomic analysis of isogenic rice reveals proteins correlated with aroma compound biosynthesis at different developmental stages. - Molecular Biotechnology 58(2): 117-129. 
[47] Wu, M. L., Chou, K. L., Wu, C. R., Chen, J. K., Huang, T. C. (2009): Characterization and the possible formation mechanism of 2-acetyl-1pyrroline in aromatic vegetable soybean (Glycine max L.). - Journal of Food Science 74(5): 192-197.

[48] Xue, Y., Duan, H., Liu, L., Wang, Z., Yang, J., Zhang, J. (2013): An improved crop management increases grain yield and nitrogen and water use efficiency in rice. - Crop Science 53(1): 271-284.

[49] Yang, S. Y., Zou, Y. B., Liang, Y. Z., Xia, B., Liu, S. K., Ibrahim, M., Li, D. Q., Li, Y. Q., Chen, L., Zeng, Y., Liu, L., Chen, Y., Li, P., Zhu, J. W. (2012): Role of soil total nitrogen in aroma synthesis of traditional regional aromatic rice in China. - Field Crops Research 125: 151-160.

[50] Ye, Y. S., Liang, X. Q., Chen, Y. X., Liu, J., Gu, J. T., Guo, R., Li, L. (2013): Alternate wetting and drying irrigation and controlled-release nitrogen fertilizer in late-season rice: effects on dry matter accumulation, yield, water and nitrogen use. - Field Crops Research 144: 212-224.

[51] Yoshihashi, T., Huong, N. T. T., Inatomi, H. (2002): Precursors of 2-Acetyl-1-pyrroline, a potent flavor compound of an aromatic rice variety. - Journal of Agricultural and Food Chemistry 50(7): 2001-2004.

[52] Zhang, C., Lu, Q., Verma, D. P. S. (1995): Removal of feedback inhibition of $\Delta^{1}$ pyrroline-5-carboxylate synthetase, a bifunctional enzyme catalyzing the first two steps of proline biosynthesis in plants. - Journal of Biological Chemistry 270(35): 20491-20496.

\section{APPENDIX}

Analysis of variance for Effect of mild drought and nitrogen on the 2-AP content in brown rice

\begin{tabular}{c|c|c|c|c}
\hline \multirow{2}{*}{ 2-AP content } & \multicolumn{2}{|c|}{ Early season } & \multicolumn{2}{c}{ Late season } \\
\cline { 2 - 5 } & Basmati 385 & Nongxiang18 & Basmati 385 & Nongxiang18 \\
\hline W(Water treatment ) & $\mathrm{ns}$ & $\mathrm{ns}$ & $* *$ & $\mathrm{~ns}$ \\
$\mathrm{~N}($ Nitrogen treatment) & $\mathrm{ns}$ & $\mathrm{ns}$ & $* *$ & $* *$ \\
$\mathrm{~W} * \mathrm{~N}$ & $\mathrm{~ns}$ & $\mathrm{~ns}$ & $\mathrm{~ns}$ & $* *$ \\
\hline
\end{tabular}

*means significant $(\mathrm{P}<0.05), * *$ means highly significant $(\mathrm{P}<0.01)$, ns, nonsignificant, the same below

Analysis of variance for effect of mild drought and nitrogen on proline and enzymes involved in 2-AP biosynthesis in grains of fragrant rice

\begin{tabular}{|c|c|c|c|c|c|c|c|}
\hline & & & Proline & PDH & OAT & P5CS & P5C \\
\hline \multirow{6}{*}{ Early season } & \multirow{3}{*}{ Basmati 385} & $\mathrm{~W}$ (Water treatment) & ns & ns & ns & $*$ & ns \\
\hline & & $\mathrm{N}$ (Nitrogen treatment) & $\mathrm{ns}$ & $\mathrm{ns}$ & $*$ & $\mathrm{~ns}$ & ns \\
\hline & & $\mathrm{W} \times \mathrm{N}$ & $\mathrm{ns}$ & $\mathrm{ns}$ & $\mathrm{ns}$ & $\mathrm{ns}$ & ns \\
\hline & \multirow{3}{*}{ Nongxiang18 } & $\mathrm{W}$ (Water treatment) & $* *$ & $*$ & $\mathrm{~ns}$ & $\mathrm{~ns}$ & ns \\
\hline & & $\mathrm{N}$ (Nitrogen treatment) & $\mathrm{ns}$ & ns & $\mathrm{ns}$ & ns & ns \\
\hline & & $\mathrm{W} \times \mathrm{N}$ & $\mathrm{ns}$ & $\mathrm{ns}$ & ns & ns & ns \\
\hline \multirow{6}{*}{ Late season } & \multirow{3}{*}{ Basmati 385} & $\mathrm{~W}$ (Water treatment) & $\mathrm{ns}$ & $\mathrm{ns}$ & $*$ & $\mathrm{~ns}$ & ns \\
\hline & & $\mathrm{N}$ (Nitrogen treatment) & $\mathrm{ns}$ & $\mathrm{ns}$ & $\mathrm{ns}$ & ns & ns \\
\hline & & $\mathrm{W} \times \mathrm{N}$ & $\mathrm{ns}$ & $*$ & $\mathrm{~ns}$ & $\mathrm{~ns}$ & ns \\
\hline & \multirow{3}{*}{ Nongxiang18 } & $\mathrm{W}$ (Water treatment) & $\mathrm{ns}$ & $\mathrm{ns}$ & $\mathrm{ns}$ & $\mathrm{ns}$ & ns \\
\hline & & $\mathrm{N}$ (Nitrogen treatment) & $\mathrm{ns}$ & $*$ & $\mathrm{~ns}$ & ns & ns \\
\hline & & $\mathrm{W} \times \mathrm{N}$ & $\mathrm{ns}$ & $\mathrm{ns}$ & ns & $\mathrm{ns}$ & ns \\
\hline
\end{tabular}




$$
-7758-
$$

Analysis of variance for effect of mild drought and nitrogen on proline, protein and enzymes involved in 2-AP biosynthesis in the leaves of fragrant rice

\begin{tabular}{|c|c|c|c|c|c|c|c|}
\hline & & & Proline & PDH & OAT & P5CS & P5C \\
\hline \multirow{6}{*}{ Early season } & \multirow{3}{*}{ Basmati 385} & $\mathrm{~W}($ Water treatment) & $\mathrm{ns}$ & $\mathrm{ns}$ & $\mathrm{ns}$ & $\mathrm{ns}$ & $* *$ \\
\hline & & $\mathrm{N}($ Nitrogen treatment) & ns & $*$ & $\mathrm{~ns}$ & $\mathrm{~ns}$ & ns \\
\hline & & $\mathrm{W} \times \mathrm{N}$ & ns & ns & $* *$ & $\mathrm{~ns}$ & ns \\
\hline & \multirow{3}{*}{ Nongxiang18 } & $\mathrm{W}($ Water treatment $)$ & $*$ & ns & $\mathrm{ns}$ & $\mathrm{ns}$ & $*$ \\
\hline & & $\mathrm{N}($ Nitrogen treatment) & $* *$ & ns & $\mathrm{ns}$ & $\mathrm{ns}$ & $*$ \\
\hline & & $\mathrm{W} \times \mathrm{N}$ & $* *$ & $*$ & ns & $\mathrm{ns}$ & ns \\
\hline \multirow{6}{*}{ Late season } & \multirow{3}{*}{ Basmati 385} & $\mathrm{~W}($ Water treatment $)$ & $* *$ & $\mathrm{~ns}$ & $*$ & $* *$ & ns \\
\hline & & $\mathrm{N}$ (Nitrogen treatment) & $*$ & $\mathrm{~ns}$ & $* *$ & $\mathrm{~ns}$ & ns \\
\hline & & $\mathrm{W} \times \mathrm{N}$ & ns & $\mathrm{ns}$ & $* *$ & $\mathrm{~ns}$ & ns \\
\hline & \multirow{3}{*}{ Nongxiang18 } & $\mathrm{W}(\mathrm{W}$ ater treatment $)$ & $\mathrm{ns}$ & $\mathrm{ns}$ & $\mathrm{ns}$ & $\mathrm{ns}$ & ns \\
\hline & & $\mathrm{N}($ Nitrogen treatment) & ns & $* *$ & $*$ & $* *$ & $* *$ \\
\hline & & $\mathrm{W} \times \mathrm{N}$ & ns & $*$ & $*$ & $\mathrm{~ns}$ & $* *$ \\
\hline
\end{tabular}

Analysis of variance for effect of mild drought and nitrogen on yield and yield components of fragrant rice

\begin{tabular}{|c|c|c|c|c|c|c|c|}
\hline & & & $\begin{array}{l}\text { Panicles } \\
\text { number }\end{array}$ & $\begin{array}{c}\text { Grains per } \\
\text { panicle }\end{array}$ & $\begin{array}{c}\text { Filled grain } \\
\text { percentage }\end{array}$ & $\begin{array}{c}\text { 1000-grain } \\
\text { weight }\end{array}$ & $\begin{array}{l}\text { Grain } \\
\text { yield }\end{array}$ \\
\hline \multirow{6}{*}{ Early season } & \multirow{3}{*}{ Basmati 385} & $\mathrm{~W}$ (Water treatment) & $\mathrm{ns}$ & ns & $\mathrm{ns}$ & $*$ & ns \\
\hline & & $\mathrm{N}($ Nitrogen treatment) & $\mathrm{ns}$ & ns & $\mathrm{ns}$ & $* *$ & ns \\
\hline & & $\mathrm{W} \times \mathrm{N}$ & $\mathrm{ns}$ & $\mathrm{ns}$ & $\mathrm{ns}$ & $* *$ & $\mathrm{~ns}$ \\
\hline & \multirow{3}{*}{ Nongxiang18 } & $\mathrm{W}($ Water treatment) & $\mathrm{ns}$ & ns & $\mathrm{ns}$ & $\mathrm{ns}$ & $\mathrm{ns}$ \\
\hline & & $\mathrm{N}($ Nitrogen treatment) & $\mathrm{ns}$ & $\mathrm{ns}$ & $\mathrm{ns}$ & $\mathrm{ns}$ & $\mathrm{ns}$ \\
\hline & & $\mathrm{W} \times \mathrm{N}$ & $\mathrm{ns}$ & ns & $\mathrm{ns}$ & $\mathrm{ns}$ & ns \\
\hline \multirow{6}{*}{ Late season } & \multirow{3}{*}{ Basmati 385} & W(Water treatment) & ns & ns & ns & ns & ns \\
\hline & & $\mathrm{N}$ (Nitrogen treatment) & $\mathrm{ns}$ & ns & $\mathrm{ns}$ & $*$ & $\mathrm{~ns}$ \\
\hline & & $\mathrm{W} \times \mathrm{N}$ & $\mathrm{ns}$ & ns & $\mathrm{ns}$ & ns & $*$ \\
\hline & \multirow{3}{*}{ Nongxiang18 } & $\mathrm{W}($ Water treatment) & $\mathrm{ns}$ & $\mathrm{ns}$ & $\mathrm{ns}$ & $*$ & * \\
\hline & & $\mathrm{N}($ Nitrogen treatment) & $\mathrm{ns}$ & ns & $\mathrm{ns}$ & $\mathrm{ns}$ & ns \\
\hline & & $\mathrm{W} \times \mathrm{N}$ & ns & ns & $* *$ & $\mathrm{~ns}$ & $\mathrm{~ns}$ \\
\hline
\end{tabular}

